\title{
Master of Research in Psychology Applied to Education: Research Projects. Generation 2017-2019
}

\author{
DOI: $10.46981 /$ sjhv2n2-013
}

Received in: April 1st, 2021

Accepted in: May 31th, 2021

\author{
Zepeta García Enrique \\ Maestría en Sistemas de Información \\ Universidad Veracruzana (Institute of Psychology and Education) \\ Agustín Melgar Esquina Juan Escutia, Col. Revolución, Xalapa, Veracruz, México \\ E-mail: ezepeta@uv.mx \\ Luna Domínguez Teresa de Jesús Pomposa \\ Doctora en Educación \\ Universidad Veracruzana (Institute of Psychology and Education) \\ Agustín Melgar Esquina Juan Escutia, Col. Revolución, Xalapa, Veracruz, México \\ E-mail: tluna@uv.mx \\ Escudero Campos Dinorah Arely \\ Doctora en Educación \\ Universidad Veracruzana (Institute of Psychology and Education) \\ Agustín Melgar Esquina Juan Escutia, Col. Revolución, Xalapa, Veracruz, México \\ E-mail: descudero@uv.mx
}

\section{RESUME}

The objective of this study was to analyze the research projects presented by MIPAE students of the 2017-2019 generation. A non-probabilistic sample of 18 students who presented research summaries for the XV Research Colloquium of the Multiregional Network of Quality Master's Programs in Psychology was studied. Procedure. Ex post facto study of a single group to determine the characteristics of the summary presented as an academic element during the training process to carry out research activities. It was found that most of the abstracts correspond to $67 \%$ the behavioral approach. The projects are mostly focus on the educational field where: $38 \%$ corresponds to Basic Education. It is identified a very wide range of the objects of study of the diverse research from the students: Behavior modification training to teachers from primary education, Musical learning behavior, Parenting patterns and child disruptive behavior, Learning of competences of research, among others. The research projects of the MIPAE students are developed under two psychological approaches: behavioral and inter-behavioral.

Keywords: Quality Postgraduate Programs, Research Training, Knowledge Networks.

\section{INDRODUCTION}

In relation to the national need for specialized professionals who impact on the economic and social development of Mexico, the Sectorial Education Program 2013-2018 through the National Council of Science and Technology (CONACyT) proposes to promote education, scientific and technological research in higher education institutions and public research centers, to favor the generation and application of knowledge that allows transformation of the country. The CONACyT is 
proposed as a Vision towards 2025: contribute to the increase of Mexico's international participation in the generation, acquisition and dissemination of knowledge, as well as scientific and technological culture on the part of society. For this, it has as a Mission: to promote scientific development and technological modernization of the country, through the training of its human resources, the promotion and support of specific research projects as well as scientific and technological dissemination (Secretaría de Educación Pública, [SEP], 2013). In this context of public policy to promote quality, CONACyT (2014), implements the National Quality Postgraduate Program (PNPC); entering this program represents a public recognition of the quality of postgraduate courses and with it the high-level of human resource training. The Sectorial Education Program suggests promoting the quality postgraduate courses of CONACyT to build: "knowledge networks in which higher education institutions participate, and support them so that their internal organization favors the bonding with the productive and social requirements" (SEP, 2013, p. 28). The meaning of the networks and academic societies in various fields of knowledge, as Silvio (2010) points out, are groups of scientists brought together in order to cooperate to achieve a common objective. In addition to these groups, and with an associative and management dynamic scheme, networks of researchers have become widespread, meeting to research and discuss a problem of common interest, in one or more disciplines; the emphasis is research, the work theme: cooperation and development. The CONACyT, through its PNPC program, proposes as a unit of organization to achieve the objectives of quality education, the creation and promotion of "Academic Bodies" (CA's) so that "Higher Educational Institutions" (IES) consider it as a policy in order to strengthen sustained dynamics by collaborative work, structuring disciplinary teams. The CA's is a group of full-time professors who in the public universities share common academic goals and objectives through the development of one or more "Lines of Generation and Application of Knowledge" (LGAC), which are specified in projects on disciplinary or multidisciplinary topics. Additionally, the members of the CA's attend Educational Programs at various levels for the fulfillment of institutional substantive functions. The LGAC is a coherent series of projects, activities or studies with a set of academic objectives and goals. It is very frequent that the generation of knowledge, in all fields, lead to the development of innovative applications for the benefit of society (SEP, 2007). In 2003 the leaders of the National Council for Teaching and Research in Psychology (CNEIP), convened coordinators of the postgraduate courses belonging to the Integral Program for the Strengthening of Postgraduate Studies (PIFOP) to constitute the Multiregional Network of Quality Master's Programs in Psychology (RMPMCP). In 2011 the agreements were: 1) to maintain and to strengthen the RMPPCP; 2) to hold an annual colloquium; 3) to make use of new technologies; 4) to promote mobility and exchange of students and teachers when financial conditions permit, and 5) to associate students' thesis with the research lines of each CA's. It is also agreed to disseminate the information of the postgraduate programs that form the 
network through a webpage of the sites of each program. In addition, at the proposal of a Director, Deputy Director or Coordinator of the postgraduate programs of the Network, it may be incorporated into other postgraduate programs in psychology that belong to the national quality postgraduate standard.

The Master of Research in Psychology Applied to Education (MIPAE) is one of the programs of the network, and is taught at the Institute of Psychology and Education from the Veracruzana University (IPyEUV). The program aimed at: the training of human resources of excellence in research in psychology applied to education, through the development of competencies to carry out scientific research and thus prepare cadres of highly trained professionals to identify, analyze and solve problems of psychological nature in the educational field. The main academic activity in each of these colloquia has been the presentation of thesis projects by the students, the evaluation and the feedback from the teachers. The LAGC developed by teachers or researchers who are directors of these investigations are also disclosed. Reading comprehension is considered relevant in the training of students, because large part of student learning is carried out through the reading of texts (Guerra-García y Guevara Benítez, 2021).

In this study, an analysis of the research projects presented by the students of the MIPAE from the generation 2017-2019 is carried out.

\section{METHOD}

\subsection{PARTICIPANTS}

A non-probabilistic sample of 18 students who presented research summaries for the XV Research Colloquium of the Multiregional Network of Quality Master's Programs in Psychology.

\subsection{RESOURCES}

- Human resources: three researchers responsible for the study with disciplinary training in psychology and education.

- Materials and equipment: three desktop computers, a video projector, laser printer, office environment Office for Windows, SPSS version 17 for Windows, and office supplies.

\subsection{PROCEDURE}

Ex post facto study of a single group with meta-analytical purposes to determine the characteristics of the summary presented as an academic element during the training process to carry out research activities.

A) Collection and capture of summaries.

B) Numerical and Graphic Analysis. By total data group, of the projects of the MIPAE 
postgraduate program member of the Multiregional Network of Quality Graduate Programs in Psychology.

C) Drafting of the results obtained to date.

\section{RESULTS}

With this document it is proposed to recognize the favorable impact of the Colloquium carried out by the RMPPCP for the training of quality teachers and for the generation and application of knowledge within CA's that contribute to the development of a quality education. It is considered important and pertinent to record the work carried out within these Colloquium that also serve as a precedent for future events organized by the RMPPCP. This report corresponds to the works that were presented in the XV Colloquium of the RMPPCP, in the city of Monterrey in Nuevo León, in the month of May of this current year, research works of 18 (100\%) students of the Master in Research in Psychology Applied to Education from the Veracruzana University. In relation to works, the psychological approach they use in their research, students declare that $67 \%$ corresponds to the behavioral approach, 28\% to the inter-behavioral and 5\% do not declare the approach, see Figure 1.

Figure 1. Psychological approach of the research carried out by the students of the MIPAE

\section{Psychological approach}

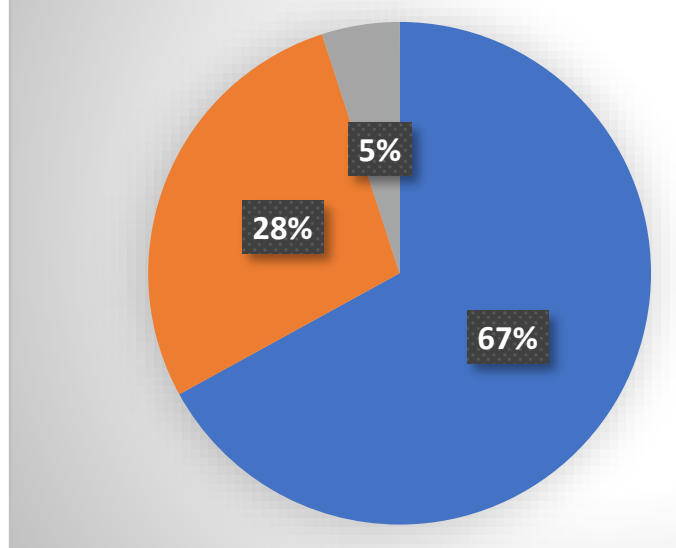

Behavioral approach

- Inter-behavioral approach

Do not declare the approach

Regarding the context of application, it is observed that the projects are mostly focus on the educational field where: $38 \%$ corresponds to Basic Education, 22\% Higher Education, 16\% Preschool Education, 6\% Special Education, on the other part other 6\% focused on the Working Environment, 6\% on the Organizational and 6\% on the Familiar. See Figure 2. 
Figure 2. Context of Application of the research carried out by the students of the MIPAE.

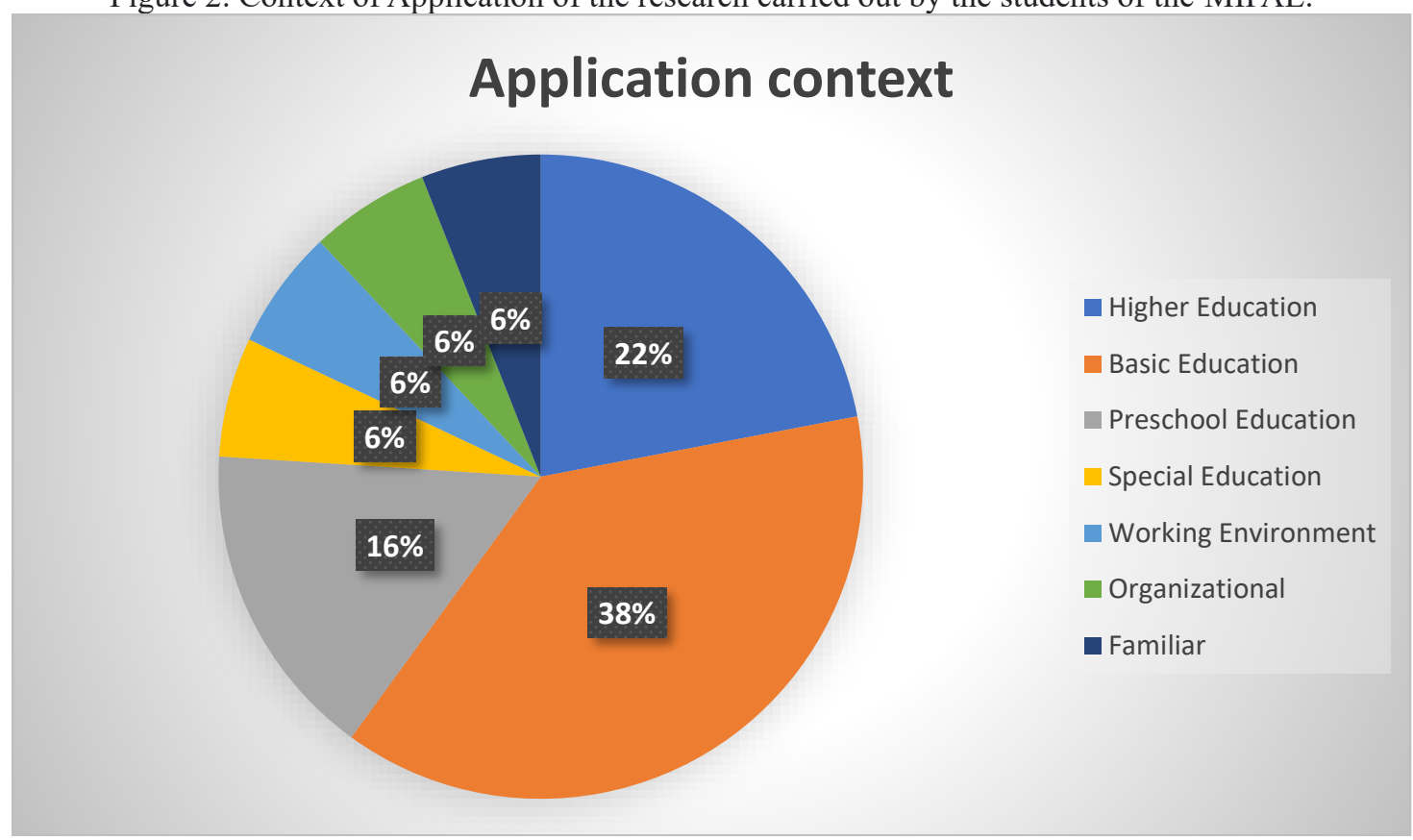

In relation to the object of study, a great diversity is presented, as you can see in table 1.

Table 1 Object of study of the research carried out by the students of the MIPAE.

\begin{tabular}{|l|l|l|l|l|}
\hline \multicolumn{2}{|l|}{ Object of study } & $\begin{array}{l}\text { Behavior modification } \\
\text { training to teachers from } \\
\text { primary education } \\
\text { behavior } \\
\text { pring } \\
\text { motor skills }\end{array}$ & $\begin{array}{l}\text { Evaluation of basic } \\
\text { Personalized } \\
\text { instruction as a strategy } \\
\text { for use of quotes and } \\
\text { APA references }\end{array}$ & $\begin{array}{l}\text { Contingent } \\
\text { relationships } \\
\text { in multigrade } \\
\text { school }\end{array}$ \\
\hline $\begin{array}{l}\text { Disturbing } \\
\text { behaviors }\end{array}$ & Teaching of language & $\begin{array}{l}\text { Behavioral transitions } \\
\text { of children with deficit } \\
\text { of attention disorder } \\
\text { and hyperactivity }\end{array}$ & Sexual behavior & \\
\hline Aggression & $\begin{array}{l}\text { Learning of competences of } \\
\text { research }\end{array}$ & $\begin{array}{l}\text { Analysis of behavior } \\
\text { problems } \\
\text { competencies }\end{array}$ & $\begin{array}{l}\text { Children values in } \\
\text { primary education }\end{array}$ & \\
\hline $\begin{array}{l}\text { Working } \\
\text { Training }\end{array}$ & $\begin{array}{l}\text { Development of cooperative } \\
\text { cinguistic qualification }\end{array}$ & $\begin{array}{l}\text { Parenting patterns and } \\
\text { child } \\
\text { behavior }\end{array}$ & \\
\hline
\end{tabular}

The main research population of the projects are the students, from basic level up to higher education as well as mothers and teachers. See Table 2.

Table 2: Population that is investigated in the projects of the students of the MIPAE

\begin{tabular}{|c|c|c|c|}
\hline \multicolumn{4}{|l|}{ Population } \\
\hline Musicians & Preschool children & Elementary teachers & Bachelor students \\
\hline School children & Children with special needs & Mothers of families & Postgraduate students \\
\hline
\end{tabular}




\section{COMMENTS}

The research projects of the MIPAE students are developed under two psychological approaches: behavioral and inter-behavioral. The different areas of application are school, family and work, however no project is developed in the clinical or health field. It is identified a very wide range of the objects of study of the diverse research from the students. They try to address current problems of greater incidence in society, which results in fulfilling the established objectives by the PSE 2013-2018 and CONACyT. 


\section{REFERENCES}

Guerra-García, J. y Guevara Benítez, C. Y. (jan/mar, 2021). Comprensión lectora en estudiantes universitarios. South Florida Journal of Health. Miami. 2(1). DOI: 10.46981/sfjhv2n1-014

Secretaría de Educación Pública (2007). Reglas de Operación del Programa de Mejoramiento del Profesorado. Recovered from:

http://www.funcionpublica.gob.mx/scagp/dgorcs/reglas/2007/11\%20SEP\%2007/1105\%20SEP\%2007 \%20PROMEP\%20ROP\%20280207.DOC

Secretaria de Educación Pública. (2013). Programa Sectorial de Educación 2013-2018. México, D.F. Recovered from: http://www.sep.gob.mx/work/models/sep1/Resource/4479/4/images/PROGRAMA_SECTORIAL_DE _EDUCACION_2013_2018_WEB.pdf

Silvio, J. (2010). Redes académica y gestión del conocimiento en américa latina: en busca de la calidad. Educación superior y sociedad, 3 (2), 7-22. http://ess.iesalc.unes co.org.ve/index.php/es 